\title{
Synthesis and in vitro Anti-HIV Screening of Certain 2-(Benzoxazol-2-ylamino)-
}

\section{H-4-oxopyrimidines}

\author{
Sherif A. F. Rostom ${ }^{1 *}$, Hesham T. Y. Fahmy ${ }^{2}$, Manal N. S. Saudi ${ }^{3}$ \\ 1 Division of Medicinal Chemistry, Faculty of Medicine and Allied Sciences, King Abdul-Aziz \\ University, P.O. Box 80205, Jeddah 21589, Kingdom Saudi Arabia. \\ 2 School of Pharmacy, University of Mississippi, Mississippi 38677, USA \\ 3 Department of Pharmaceutical Chemistry, Faculty of Pharmacy, Alexandria University, 21215 \\ Alexandria, A. R. Egypt.
}

Intensive efforts are underway worldwide to develop chemotherapeutic agents effective against HIV, the etiological agent of AIDS. In this view, it was designed to synthesize and investigate the anti-HIV activity of some new 2-(benzoxazol-2-ylamino)-3H-4-oxopyrimidines following the lead benzoxazole ( $\mathrm{L} 697,661$ ), which was reported to inhibit the spread of the HIV infection by $95 \%$ in $\mathrm{MT}_{4}$ cell culture. Only the 2-(benzoxazol-2-ylamino)-6-hydroxy-3H-4-oxopyrimidine 8 (NSC 722448 ) was confirmed to exhibit moderate in vitro anti-HIV activity (percentage of protection $76.83 \%)$.

(Keywords: HIV, AIDS, Benzoxazoles, Pyrimidines, Anti-HIV screening)

\section{Introduction}

The discovery of human immunodefficiency virus 1 (HIV-1) as the causative agent of the acquired immunodefficiency syndrome (AIDS) in $1983^{1}$ stimulated an unprecedented level of research activity directed towards both the prevention and treatment of this debilitating lethal disease. Despite the international efforts to control HIV / AIDS pandemic through behavioral modifications and other interventions, more than 15,000 people become infected every day, $95 \%$ of whom live in developing countries ${ }^{2,3}$. Information about the genomic structure and replication 
cycle of retroviruses has facilitated the identification of the biochemical targets for attack by potential therapeutic agents for the treatment of HIV infection. Many of these targets are key proteins involved in the HIV replication cycle. These include formation of proviral DNA by the reverse transcriptase enzyme (RT), integration of proviral DNA into the host DNA by the integrase enzyme, and cleavage of the precursor viral proteins by the protease enzyme ${ }^{4}$. In recent years, particular attention has been focussed on the biological significance of the virally encoded RT enzyme, which mediates the conversion of viral RNA genome to proviral DNA ${ }^{5}$. Therefore, clinically relevant agents which have been successfully developed are the RT inhibitors, which in their turn are classified into two main categories: nucleoside RT inhibitors (NRTIs) and nonnucleoside RT inhibitors (NNRTIs). NRTIs such as $3^{\prime}$-azidothymidine (AZT) and dideoxyinosine (ddI) act by competitive inhibition of HIV RT through incorporation into the growing viral DNA chain and cause chain termination. They require intracytoplasmic activation by cellular enzyme to the triphosphate form ${ }^{6}$. They are now used clinically for the treatment of HIV infections, however, their use is limited by their significant toxicities ${ }^{7}$. On the other hand, NNRTIs are a diverse group of compounds that share a number of common biochemical and pharmacological properties. Recently, De Clercq ${ }^{8}$ has reported that at least thirty different classes of NNRTIs are available. Unlike the nucleoside antimetabolites, the NNRTIs do not require bioactivation. They block the HIV RT reaction through interaction with an allosterically located non-substrate binding site by a non competitive mechanism. When bound into their pocket at the HIV RT, the NNRTIs maintain a very similar conformational shape. They roughly overlay each other in the binding pocket and appear to function as $\pi$-electron donors to aromatic side chain residues surrounding the pocket ${ }^{9}$. NNRTIs are extremely potent and selective as they do not inhibit RT of other retroviruses including HIV-2. They have high therapeutic indices (in contrast to nucleosides) and do not inhibit mamalian DNA polymerases ${ }^{10}$. As NNRTIs interact with a specific binding site on the enzyme, any slight 
<smiles>Cc1cc(NCc2nc3c(Cl)ccc(Cl)c3o2)c(=O)[nH]c1C</smiles>

$L-697,661$<smiles>O=c1[nH]c(Nc2nc3ccccc3[nH]2)nc(O)c1-c1ccccc1</smiles>

NSC 666268

variation brought about by a single point mutation can have a significant impact on the sensitivity of the virus towards members of this group, and high-level resistance can develop quickly ${ }^{11}$. Among the already reported distinctive NNRTIs, 3-[(4,7-dichlorobenzoxazol-2-yl)-methylamino]-5-ethyl-6methylpyridin-2(1H)-one; (L 697, 661) was reported to inhibit the spread of the HIV infection by $95 \%$ in $\mathrm{MT}_{4}$ cell culture. On basis of potency, selectivity, oral bioavailability and appropriate safety and tolerability studies, this lead compound was selected for phase 1 clinical trials to determine these parameters in $\operatorname{man}{ }^{12}$.

The pre-mentioned considerations highlight the importance and the urgent need to continue searching for new more potent, less toxic and more selective anti-HIV agent. In this view, and as a result of the recent growing interest of benzoxazoles as chemotherapeutic agents ${ }^{13-18}$, it was designed to synthesize and investigate the anti-HIV activity of some new 2-(benzoxazol-2ylamino)-3H-4-oxopyrimidines. The newly synthesized compounds are structurally related to the lead compound ( $\mathrm{L} 697,661)$ which constitutes the benzoxazole ring linked at $\mathrm{C}_{2}$ to a pyridone moiety through a two atom spacer. The target compounds were patterned so as to comprise the benzoxazole and the bioisosteric pyrimidinone counterparts separated by NH linker. In addition, the pyrimidinone moiety is considered as an essential component in many nucleoside and nonnucleoside antiviral agents ${ }^{19-21}$. The substitution pattern of the pyrimidinone ring was carefully 
60

S. A. F. Rostom et al.:

selected so as to confer different electronic environment to the molecule and believed to be responsible for such biological activity in structurally relevant compounds such as NSC $66626{ }^{22}$. It was also attempted to investigate the previously reported, structurally related compound 2(benzoxazol-2-ylamino)-6,7-dihydro-3H,5H-cyclopenta[d]pyrimidin-4(3H)-one ${ }^{23}$ for its anti-HIV activity.

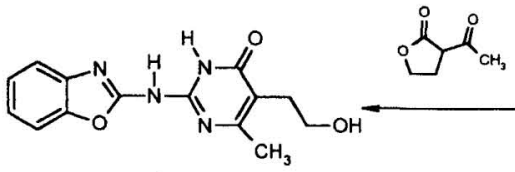

2
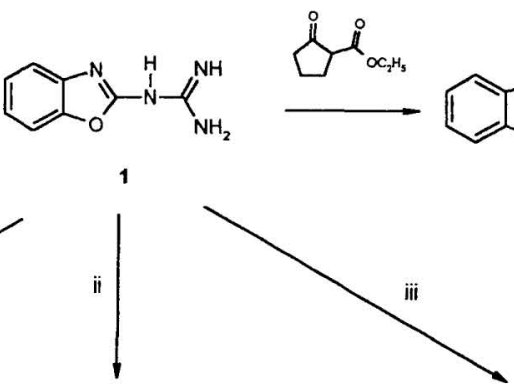

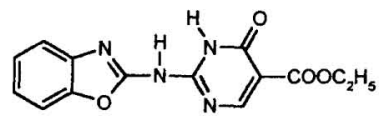

3

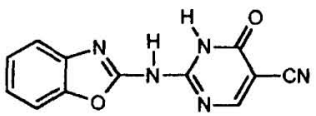

4

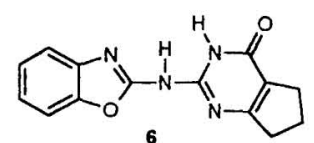

6

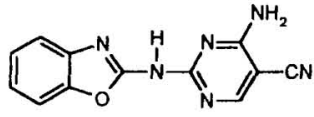

5

i : $\mathrm{C}_{2} \mathrm{H}_{5} \mathrm{O}-\mathrm{CH}=\left(\mathrm{COOC}_{2} \mathrm{H}_{5}\right)_{2}$, ii : $\mathrm{C}_{2} \mathrm{H}_{5} \mathrm{O}-\mathrm{CH}=\mathrm{C}(\mathrm{CN}) \mathrm{COOC}{ }_{2} \mathrm{H}_{5}$, iii : $\mathrm{C}_{2} \mathrm{H}_{5} \mathrm{O}-\mathrm{CH}=(\mathrm{CN})_{2}$

Scheme 1 


\section{Results and Discussion}

\section{Chemistry}

The synthetic strategies adopted to obtain the target compounds are depicted in schemes 1 and 2 . The starting compound, 2-guanidinobenzoxazole 1, was successfully synthesized according to the method described by Dersch and Angelus ${ }^{24}$. The method involved heating 2-amiophenol with dicyandiamide in concentrated hydrochloric acid followed by neutralization with $40 \%$ sodium hydroxide. Condensing 1 with 2-acetylbutyrolactone in refluxing bromobenzene afforded the 2(benzoxazol-2-ylamino)-5-(2-hydroxyethyl)-6-methyl-3H-4-oxopyrimidine 2. Reacting 1 with diethyl ethoxymethylenemalonate in refluxing acetonitrile in the presence of anhydrous potassium carbonate yielded the corresponding ethyl 2-(benzoxazol-2-ylamino)-3 $H$-4-oxopyrimidine-5carboxylate 3. Analogously, condensing 1 with ethyl ethoxy-methylenecyanoacetate and ethoxymethylenemalononitrile in absolute ethanol, resulted in the formation of the corresponding 2(benzoxazol-2-ylamino)-5-cyano-3H-4-oxopyrimidine 4 and 4-amino-2-(benzoxazol-2-ylamino)-5cyanopyrimidine 5, respectively. For the synthesis of the previously described compound 6; 2(benzoxazol-2-ylamino)-6,7-dihydro-3H,5H-cyclopenta[d]pyrimidin-4(3H)-one ${ }^{23}$, a new procedure with improved yield and purity was developed. It involved fusion of 1 with ethyl cyclopentanone-2carboxylate (scheme 1).

On the other hand, heating 1 with the appropriate ethyl 2-arylazo-3-oxobutyrate ${ }^{25}$ in anhydrous methanol in the presence of sodium methoxide afforded the corresponding 5-arylazo-2(benzoxazol-2-ylamino)-6-methyl-3H-4-oxopyrimidines 7a-c. Condensing I with diethyl malonate in refluxing bromobenzene yielded the 2-(benzoxazol-2-ylamino)-6-hydroxy-3H-4-oxopyrimidine 8 which was converted to its dichloro analog 9 upon treatment with phosphorous oxychloride. The desired 2-(benzoxazol-2-ylamino)-6-hydroxy-5-substituted-3H-4-oxopyrimidines 10a-c were prepared by heating the key intermediate 1 with an excess of the appropriate substituted diethyl 
malonate. Compounds 11a-c; 5-arylazo-2-(benzoxazol-2-ylamino)-6-hydroxy-3H-4oxopyrimidines; were prepared by coupling 8 with the selected diazonium salt in the presence of sodium hydroxide and sodium acetate followed by acidification with hydrochloric acid (scheme 2 ).

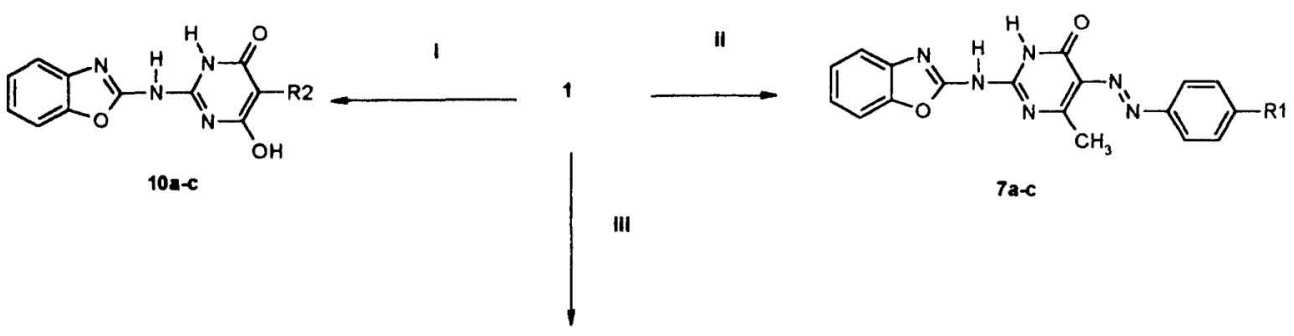<smiles>[R1]c1ccc(N=Nc2c(O)nc(N3C=Nc4ccccc4O3)[nH]c2=O)cc1</smiles>

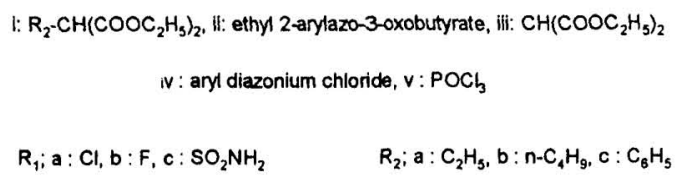

Scheme 2

\section{In vitro anti-HIV screening}

Fourteen of the newly synthesized compounds namely, 2-5, 7a-c, 8, 9, 10a-c and 11a,b together with the previously reported $6^{23}$, were selected by the National Cancer Institute (NCI), Developmental Therapeutics Program (DTP), AIDS antiviral program, to be screened for their in 
vitro effect on HIV-induced cytopathogenicity in a human $T_{4}$ lymphocyte cell line ${ }^{26.27}$. Activity is expressed in terms of the percent of protection which is the percentage of surviving HIV-infected cells treated with test compounds (at the indicated concentrations) relative to the same uninfected untreated controls. Three response parameters were determined for each testing compound. The effective concentration $50 \%\left(\mathrm{EC}_{50}\right)$, represents compound's concentration resulting in $50 \%$ reduction of viral cytopathic effect. The $50 \%$ inhibitory concentration $\left(\mathrm{IC}_{50}\right)$, corresponds to drug's concentration that result in $50 \%$ growth inhibition of normal, uninfected cells. The therapeutic index (TI) was determined by dividing $\left(\mathrm{IC}_{50}\right)$ by $\left(\mathrm{EC}_{50}\right)$. The results were compared with $\mathrm{AZT}$, the positive control, was carried out at the same time under the same conditions and are recorded in table 1 .

Out of the compounds tested, only the 2-(benzoxazol-2-vlamino)-6-hydroxy-3H-4-oxopyrimidine 8 (NSC 722448) exhibited reproducible moderate in vitro anti-HIV activity (percent of protection $76.83 \%)$ i.e. it showed a $50 \%$ or greater reduction of viral cytopathic effect in two or more independent experiments (Table 1). The recorded $\mathrm{IC}_{50 \%}$ and $\mathrm{EC}_{50 \%}$ values were 68.0 and $12.1 \mu \mathrm{M}$, respectively, however, the therapeutic index (TI) was 5.62 which was not sufficient for further in vivo testing when compared with AZT (TI $\left.>3.89 \times 10^{-2}\right)$. Moreover, although compound 11a, 4chlorophenylazo-2-(benzoxazol-2-ylamino)-6-hydroxy-3H-4-oxopyrimidine, showed percent of protection $52.15 \%$, yet it was confirmed inactive by the NCl's Developmental Therapeutics Program (Table 1).

On the other hand, the remaining compounds failed to counteract the cytopathic effect of HIV, since the cell growth of HIV-infected cells lied between 5.14-44.06 \% (Table 1). Values of cell growth of HIV-infected cells between $0-50 \%$ indicated lack of any substantial anti-HIV activity. However, all compounds failed to suppress cell proliferation of uninfected CEM cells at micromolar 
Table 1. Reduction of in vitro HIV-induced cytopathic effect (\% protection) and cytotoxic dose $\left(\mathrm{IC}_{30}, \mu \mathrm{M}\right)$ of compounds 2-11

\begin{tabular}{|c|c|c|c|}
\hline Cpd. No & Dose $(\mu M)^{n}$ & $\%$ of protection $\pm \mathrm{SE}^{b, c}$ & $I C_{50}(\mu \mathrm{M})$ \\
\hline 2 & 63.3 & $8.13 \pm 0.92$ & $>200$ \\
\hline 3 & 20.0 & $24.97 \pm 1.8$ & 37.1 \\
\hline 4 & 63.3 & $22.22 \pm 3.7$ & 96.1 \\
\hline 5 & 200 & $18.90 \pm 1.8$ & $>200$ \\
\hline 6 & 63.3 & $18.58 \pm 0.7$ & 111 \\
\hline $7 \mathbf{a}$ & 63.3 & $44.06 \pm 5.7$ & 89.7 \\
\hline $7 \mathbf{b}$ & 63.3 & $40.35 \pm 2.5$ & 76.2 \\
\hline $7 c$ & 200 & $17.04 \pm 1.1$ & $>200$ \\
\hline 8 & 20.0 & $76.83 \pm 0.5$ & $68.0^{d}$ \\
\hline 9 & 2.01 & $5.14 \pm 0.01$ & 9.91 \\
\hline $10 \mathrm{a}$ & 0.63 & $12.31 \pm 1.9$ & $>200$ \\
\hline $10 b$ & 0.63 & $14.38 \pm 1.6$ & 51.3 \\
\hline $10 c$ & 200 & $39.50 \pm 5.7$ & $>200$ \\
\hline $11 \mathrm{a}$ & 6.34 & $52.15 \pm 0.9$ & $37.1^{e}$ \\
\hline $11 b$ & 20.0 & $40.87 \pm 3.8$ & 81.2 \\
\hline AZT & $\ldots f$ & 111.76 & $>1.0^{\mathrm{g}}$ \\
\hline
\end{tabular}

\footnotetext{
a concentration at which maximum reduction of viral cytopathic effect occurred

b SE denotes the standard error $(n=4)$

c All the data are significantly different from the control (Student $t$-test, $p>0.001$ )

d $\quad \mathrm{EC}_{50}=12.1 \mu \mathrm{M} ; \mathrm{TI}=5.62$

e $\quad \mathrm{EC}_{50}=6.04 \mu \mathrm{M} ; \mathrm{TI}=6.14$

f Not mentioned

g $\quad \mathrm{EC}_{50}=>0.00257 \mu \mathrm{M} ; \mathrm{TI}>3.89 \times 10^{-2}$
}

concentrations although remarkable inhibition of cell growth was observed at much higher concentrations 
Referring to the results recorded in table 1 , one can notice that, substitution of $C_{5}$ of 2 (benzoxazol-2-vlamino)-6-hydroxy-3H-4-oxopyrimidine 8 with alkyl (aryl) or arylazo groups (as in $10 \mathrm{a}-\mathrm{c}$ and 11b) resulted in significant reduction in the anti-HIV activity (percent of protection 12.31-40.87\%). Conversion of the same derivative to the dichloro analog 9 led to almost abolishment of the biological activity (percent of protection $5.14 \%$ ).

Owing to the weak anti-HIV activity displayed by the newly synthesized compounds, it was difficult to establish a relationship between the substitution pattern of the pyrimidine ring at $\mathrm{C}_{4}, \mathrm{C}_{5}$, $\mathrm{C}_{6}$ and the biological activity. However, the anti-HIV profile of compound 8 would encourage further structural modifications.

\section{Experimental}

\section{A. Synthesis}

Melting points were determined in open-glass capillaries on a Stuart melting point apparatus and were uncorrected. The infrared (IR) spectra were recorded on 470-Shimadzu infrared spectrophotometer using the $\mathrm{KBr}$ disc technique. The ${ }^{1} \mathrm{H}-\mathrm{NMR}-(\delta$-ppm) spectra were recorded on a Bruker $(400 \mathrm{MHz})$ spectrometer using tetramethylsilane as the internal standard and DMSO- $\mathrm{d}_{6}$ as the solvent. Splitting patterns were designated as follows: s; singlet; $d$ : doublet; m: multiplet. Mass spectra were recorded on a Finnigan SSQ $7000 \mathrm{GC}-\mathrm{MS}$, ionization energy $70 \mathrm{eV}$. Elemental analyses were performed at the Microanalytical Unit, Faculty of Science, Cairo University, Cairo, Egypt, and the found values were within $\pm 0.4 \%$ of the theoretical values. Follow up of the reactions and checking the homogeneity of the compounds were made by TLC on silica gel-protected aluminum sheets (Type 60 F254, Merck) and the spots were detected by exposure to UV-lamp at $\lambda$ $254 \mathrm{~nm}$ for few seconds. 
Table 2. Physicochemical and analytical data of compounds 2-11

\begin{tabular}{|c|c|c|c|c|c|}
\hline Comp. No. & $\overline{\mathbf{R}_{1}}$ & $\mathbf{R}_{\mathbf{2}}$ & $\begin{array}{c}\text { M.P. }{ }^{\circ} \mathrm{C} \\
\text { Cryst. Sol. }\end{array}$ & $\begin{array}{l}\text { Yield } \\
(\%)\end{array}$ & $\begin{array}{c}\text { Mol. Formula }^{a} \\
\text { Mol. Weight }\end{array}$ \\
\hline \multirow[t]{2}{*}{2} & -- & -- & $184-6$ & 34.9 & $\mathrm{C}_{14} \mathrm{H}_{14} \mathrm{~N}_{4} \mathrm{O}_{3}$ \\
\hline & & & DMF & & 286.29 \\
\hline \multirow[t]{2}{*}{3} & -- & -- & $276-8$ & 41.7 & $\mathrm{C}_{14} \mathrm{H}_{12} \mathrm{~N}_{4} \mathrm{O}_{4}$ \\
\hline & & & DMF & & 300.28 \\
\hline \multirow[t]{2}{*}{4} & --- & --- & $226-8$ & 50.0 & $\mathrm{C}_{12} \mathrm{H}_{7} \mathrm{~N}_{5} \mathrm{O}_{2}$ \\
\hline & & & DMF & & 253.22 \\
\hline \multirow[t]{2}{*}{5} & -- & --- & $240-2$ & 40.0 & $\mathrm{C}_{12} \mathrm{H}_{8} \mathrm{~N}_{6} \mathrm{O}$ \\
\hline & & & DMF & & 252.24 \\
\hline \multirow[t]{2}{*}{6} & --- & --- & $140-2$ & 75.0 & $\mathrm{C}_{14} \mathrm{H}_{12} \mathrm{~N}_{4} \mathrm{O}_{2}$ \\
\hline & & & $\mathrm{DMF} / \mathrm{H}_{2} \mathrm{O}$ & & 268.28 \\
\hline \multirow[t]{2}{*}{$7 \mathbf{a}$} & $\mathrm{Cl}$ & --- & $182-4$ & 70.0 & $\mathrm{C}_{18} \mathrm{H}_{13} \mathrm{CIN}_{6} \mathrm{O}_{2}$ \\
\hline & & & $\mathrm{DMF} / \mathrm{EtOH}$ & & 380.80 \\
\hline \multirow[t]{2}{*}{$7 \mathbf{b}$} & $\mathrm{F}$ & --- & $177-9$ & 36.4 & $\mathrm{C}_{18} \mathrm{H}_{13} \mathrm{FN}_{6} \mathrm{O}_{2}$ \\
\hline & & & $\mathrm{DMF} / \mathrm{EtOH}$ & & 364.34 \\
\hline \multirow[t]{2}{*}{$7 c$} & $\mathrm{SO}_{2} \mathrm{NH}_{2}$ & -- & $230-2$ & 30.8 & $\mathrm{C}_{18} \mathrm{H}_{15} \mathrm{~N}_{7} \mathrm{O}_{4} \mathrm{~S}$ \\
\hline & & & $\mathrm{DMF} / \mathrm{EtOH}$ & & 425.43 \\
\hline \multirow[t]{2}{*}{8} & -- & -- & $>300$ & 72.2 & $\mathrm{C}_{11} \mathrm{H}_{8} \mathrm{~N}_{4} \mathrm{O}_{3}$ \\
\hline & & & $\mathrm{DMF} / \mathrm{H} 2 \mathrm{O}$ & & 244.21 \\
\hline \multirow[t]{2}{*}{9} & --- & --- & $>300$ & 71.4 & $\mathrm{C}_{11} \mathrm{H}_{6} \mathrm{Cl}_{2} \mathrm{~N}_{4} \mathrm{O}$ \\
\hline & & & DMF & & 281.10 \\
\hline \multirow[t]{2}{*}{$10 a$} & --- & $\mathrm{C}_{2} \mathrm{H}_{5}$ & $160-2$ & 36.6 & $\mathrm{C}_{13} \mathrm{H}_{12} \mathrm{~N}_{4} \mathrm{O}_{3}$ \\
\hline & & & $\mathrm{DMF} / \mathrm{H}_{2} \mathrm{O}$ & & 272.27 \\
\hline \multirow[t]{2}{*}{$10 \mathrm{~b}$} & --- & $\mathrm{n}-\mathrm{C}_{4} \mathrm{H}_{9}$ & $240-2$ & 44.4 & $\mathrm{C}_{15} \mathrm{H}_{16} \mathrm{~N}_{4} \mathrm{O}_{3}$ \\
\hline & & & HOAC & & 300.32 \\
\hline \multirow[t]{2}{*}{$10 \mathrm{c}$} & --- & $\mathrm{C}_{6} \mathrm{H}_{5}$ & $297-9$ & 57.3 & $\mathrm{C}_{17} \mathrm{H}_{12} \mathrm{~N}_{4} \mathrm{O}_{3}$ \\
\hline & & & DMF & & 320.31 \\
\hline \multirow[t]{2}{*}{$11 \mathrm{a}$} & $\mathrm{Cl}$ & & $>300$ & 64.9 & $\mathrm{C}_{17} \mathrm{H}_{11} \mathrm{ClN}_{6} \mathrm{O}_{3}$ \\
\hline & & -- & $\mathrm{DMF} / \mathrm{EtOH}$ & & 382.77 \\
\hline
\end{tabular}




\begin{tabular}{|c|c|c|c|c|c|}
\hline $11 b$ & $F$ & & $>300$ & 54.8 & $\mathrm{C}_{17} \mathrm{H}_{11} \mathrm{FN}_{6} \mathrm{O}_{3}$ \\
\hline & & -- & $\mathrm{DMF} / \mathrm{EtOH}$ & & 366.31 \\
\hline \multirow[t]{2}{*}{$11 \mathrm{c}$} & $\mathrm{SO}_{2} \mathrm{NH}_{2}$ & & $>300$ & 58.8 & $\mathrm{C}_{17} \mathrm{H}_{13} \mathrm{~N}_{7} \mathrm{O}_{5} \mathrm{~S}$ \\
\hline & & -- & DMF/EtOH & & 427.40 \\
\hline
\end{tabular}

a Analyzed for $\mathrm{C}, \mathrm{H}, \mathrm{N}, \mathrm{S}$; results are within $\pm 0.4 \%$ of the theoretical values for the formulae given

\section{2-(Benzoxazol-2-ylamino)-5-(2-hydroxyethyl)-6-methyl-3H-4-oxopyrimidine (2)}

A solution of 2-guanidinobenzoxazole $1(0.5 \mathrm{~g}, 3 \mathrm{mmol}){ }^{24}$ and 2-actylbutyro-lactone $(0.8 \mathrm{~g}, 6$ mmol) in bromobenzene $(10 \mathrm{ml})$ was refluxed for $5 \mathrm{~h}$. After cooling to room temperature, the separated solid product was filtered, washed with cold ethanol, dried and recrystallized. The physicochemical and analytical data are recorded in table 2. IR $\left(\mathrm{cm}^{-1}\right): 3650-3030(\mathrm{NH}, \mathrm{CH}, \mathrm{OH})$; $1692(\mathrm{C}=0) ; 1645,1582,1511,1460\left(\mathrm{C}=\mathrm{N}, \mathrm{C}=\mathrm{C}\right.$, amide II, Ar); 1221 (C-O-C). ${ }^{1} \mathrm{H}-\mathrm{NMR}: \delta 11.1$ (bs, $1 \mathrm{H}, \mathrm{N} H) ; 7.29$ (dd, $J=4 \mathrm{~Hz}, 2 \mathrm{H}, \mathrm{Ar}-H) ; 7.21$ (dd, $J=4 \mathrm{~Hz}, 2 \mathrm{H}, \mathrm{Ar}-H) ; 4.83(\mathrm{t}, J=4 \mathrm{~Hz}, 2 \mathrm{H}$, $\left.\mathrm{CH}_{2}\right) ; 2.95$ (t, $J=4 \mathrm{~Hz}, 2 \mathrm{H}, \mathrm{CH}$ ); 2.50 (s, 3H, $\mathrm{CH}_{3}$ ). MS, m/z (\%): $285.2\left(8, \mathrm{M}^{+}\right), 244.1$ (100), 227.2 (78), 200.2 (52), 185.2 (71), 159.2 (14), $145.2(32), 134.1$ (29).

\section{Ethyl 2-(benzoxazol-2-ylamino)-3H-4-oxopyrimidine-5-carboxylate (3)}

An equimolar mixture of $\mathbf{1}(0.7 \mathrm{~g}, 4 \mathrm{mmol})$, diethyl ethoxymethylenemalonate $(0.9 \mathrm{~g}, 4 \mathrm{mmol})$ and anhydrous potassium carbonate $(0.6 \mathrm{~g}, 4 \mathrm{mmol})$ in acetonitrile $(15 \mathrm{ml})$ was refluxed for $8 \mathrm{~h}$. After being cooled to room temperature, the yellowish solid product was separated, suspended in water and acidified with dilute hydrochloric acid till pH 3-4. The resulting creamy white precipitate was filtered, washed thoroughly with water, dried and recrystallized. The physicochemical and 
analytical data are recorded in table 2. IR $\left(\mathrm{cm}^{-1}\right): 3530-2795(\mathrm{NH}, \mathrm{CH}) ; 1709(\mathrm{C}=\mathrm{O}$ ester); 1657 (C=O amide I); 1616, 1555, 1475, $1388\left(\mathrm{C}=\mathrm{N}, \mathrm{C}=\mathrm{C}\right.$, amide II, Ar); $1226(\mathrm{C}-\mathrm{O}-\mathrm{C}) .{ }^{1} \mathrm{H}-\mathrm{NMR}: \delta 12.1$ (bs, $1 \mathrm{H}, \mathrm{N} H$ ); 8.4 (s, $1 \mathrm{H}$, pyrimidine $\left.\mathrm{C}_{6}-H\right) ; 7.52$ (dd, $\left.J=4 \mathrm{~Hz}, 2 \mathrm{H}, \mathrm{Ar}-H\right) ; 7.24$ (dd, $J=4 \mathrm{~Hz}, 2 \mathrm{H}$, $\operatorname{Ar}-H) ; 4.21$ (q, 2H, $\left.\mathrm{CH}_{2}\right) ; 1.26\left(\mathrm{t}, 3 \mathrm{H}, \mathrm{CH}\right.$ ). MS, m/z (\%): $300.2\left(100, \mathrm{M}^{+}\right), 254.1(66), 226.2(57)$, $159.2(51), 134.2(25), 104.2(12)$.

\section{2-(Benzoxazol-2-ylamino)-5-cyano-3H-4-oxopyrimidine (4)}

A solution of $1(0.7 \mathrm{~g}, 4 \mathrm{mmol})$ and ethyl ethoxymethylenecyanoacetate $(0.7 \mathrm{~g}, 4 \mathrm{mmol})$ in absolute ethanol $(15 \mathrm{ml})$ was refluxed for $4 \mathrm{~h}$ in the presence of anhydrous potassium carbonate $(0.6$ $\mathrm{g}, 4 \mathrm{mmol}$ ). The reaction mixture was worked up as described under compound 3 . The physiochemical and analytical data are recorded in table 2. $\mathbb{R}\left(\mathrm{cm}^{-1}\right): 3550-2700(\mathrm{NH}, \mathrm{CH}) ; 2225$ (CN); $1654(\mathrm{C}=\mathrm{O}$ amide $\mathrm{I}) ; 1627,1571,1544,1458,1430(\mathrm{C}=\mathrm{N}, \mathrm{C}=\mathrm{C}$, amide II, Ar); 1242 (C-OC). ${ }^{1} \mathrm{H}-\mathrm{NMR}$ : $\delta 12.3(\mathrm{bs}, 1 \mathrm{H}, \mathrm{N} H) ; 8.45\left(\mathrm{~s}, 1 \mathrm{H}\right.$, pyremidine $\left.\mathrm{C}_{6}-H\right) ; 7.26(\mathrm{dd}, J=4 \mathrm{~Hz}, 2 \mathrm{H}, \mathrm{Ar}-H)$; $7.20(\mathrm{dd}, J=4 \mathrm{~Hz}, 2 \mathrm{H}, \mathrm{Ar}-H)$. MS, m/z (\%): $253.2\left(100, \mathrm{M}^{+}\right), 225.2$ (12), $185.2(14), 159.2(48)$, $134.2(20), 120.2(10)$.

\section{4-Amino-2-(benzoxazol-2-ylamino)-5-cyanopyrimidine (5)}

The title compound was prepared, as described for compound 3 by refluxing a mixture of $1(0.7$ $\mathrm{g}, 4 \mathrm{mmol})$, ethoxymethylenemalononitrile $(0.5 \mathrm{~g}, 4 \mathrm{mmol})$ and anhydrous potassium carbonate (0.6 $\mathrm{g}, 4 \mathrm{mmol})$ in absolute ethanol $(15 \mathrm{ml})$ for $6 \mathrm{~h}$. The reaction mixture was worked up as described under compound 3. The physicochemical and analytical data are recorded in table 2 . IR $\left(\mathrm{cm}^{-1}\right)$ : 3550-2595 (NH, CH); 2220 (CN); 1619, 1590, 1561, 1458, 1427 (C=N, C=C, Ar); 1252 (C-O-C) ${ }^{1} \mathrm{H}-\mathrm{NMR}: \delta 12.2(\mathrm{bs}, 1 \mathrm{H}, \mathrm{NH}) ; 8.60(\mathrm{~s}, 1 \mathrm{H}$, pyrimidineC $6-H) ; 7.29(\mathrm{dd}, J=4 \mathrm{~Hz}, 2 \mathrm{H}, \mathrm{Ar}-H) ; 7.22$ 
(dd, $J=4 \mathrm{~Hz}, 2 \mathrm{H}, \mathrm{Ar}-H) . \mathrm{MS}, \mathrm{m} / \mathrm{z}(\%): 252.2\left(58, \mathrm{M}^{+}\right), 235.2(10), 211.2(100), 185.2(15.4), 159.2$ (22), $134.2(9), 120.2(10)$.

\section{2-(Benzoxazol-2-ylamino)-6,7-dihydro-3H,5H-cyclopenta[d]pyrimidin-4(3H)-one (6) ${ }^{23}$}

2-Guanidinobenzoxazole 1 (0.5 g, $3 \mathrm{mmol})$ and ethyl cyclopentanone-2-carboxylate $(0.9 \mathrm{~g}, 6$ mmol) were heated at $200^{\circ} \mathrm{C}$ in an oil bath for $1-2 \mathrm{~h}$. After cooling to room temperature, the product was treated with cold ethanol, filtered, washed, dried and recrystallized. The physicochemical and analytical data are recorded in table 2. IR $\left(\mathrm{cm}^{-1}\right): 3455-2655(\mathrm{NH}, \mathrm{CH}) ; 1668(\mathrm{C}=0) ; 1628,1542$, 1494, 1451 (C=N, amide II, Ar); 1221 (C-O-C). ${ }^{~} \mathrm{H}-\mathrm{NMR}: 12.3$ (bs, 2H, $2 \mathrm{NH}$ ); 7.53 (dd, $J=4 \mathrm{~Hz}$, $2 \mathrm{H}, \mathrm{Ar}-H) ; 7.26(\mathrm{dd}, J=4 \mathrm{~Hz}, 2 \mathrm{H}, \mathrm{Ar}-\mathrm{H}) ; 2.79\left(\mathrm{t}, J=4 \mathrm{~Hz}, 2 \mathrm{H}, \mathrm{CH}_{2}\right) ; 2.55\left(\mathrm{t}, J=4 \mathrm{~Hz}, 2 \mathrm{H}, \mathrm{CH}_{2}\right.$ ); 2.50 (s, 3H, $\left.\mathrm{CH}_{3}\right) ; 2.01$ (m, 2H, $\mathrm{CH}_{2}$ ). MS, m/z (\%): 268.1(100, $\left.\mathrm{M}^{+}\right), 226.1$ (44), $203.2(50), 171.2$ (12), $160.1(60), 134.1(42), 118.1(22)$.

\section{5-Arylazo-2-(benzoxazol-2-ylamino)-6-methyl-3H-4-oxopyrimidines (7a-c)}

To a solution of $1(0.5 \mathrm{~g}, 3 \mathrm{mmol})$ and sodium methoxide $(0.6 \mathrm{~g}, 3 \mathrm{mmol})$ in anhydrous methanol $(10 \mathrm{ml})$, was added the appropriate ethyl 2-arylazo-3-oxobutyrate $(3 \mathrm{mmol}){ }^{25}$. The reaction mixture was heated under reflux for $5 \mathrm{~h}$ during which a yellow product partially crystallized out. It was filtered while hot, washed with methanol, dried and recrystallized. The physicochemical and analytical data are recorded in table 2. IR $\left(\mathrm{cm}^{-1}\right): 3555-2985(\mathrm{NH}, \mathrm{CH}) ; 1690-1670(\mathrm{C}=\mathrm{O}$ amide I); 1609, 1551, 1504, 1473, $1423\left(\mathrm{C}=\mathrm{N},-\mathrm{N}=\mathrm{N}-, \mathrm{C}=\mathrm{C}\right.$, amide II, Ar); 1234 (C-O-C). ${ }^{1} \mathrm{H}-\mathrm{NMR}$ of 7a: $\delta$ 14.0 (bs, $1 \mathrm{H}, \mathrm{N} H$ ); 12.5 (bs, 1H, NH); 7.66 (dd, $J=4 \mathrm{~Hz}, 2 \mathrm{H}, \mathrm{Ar}-H) ; 7.49$ (dd, $J=4 \mathrm{~Hz}, 2 \mathrm{H}, \mathrm{Ar}-H$ ); 7.33-7.26 (m, 4H, Ar-H); 2.31 (s, 3H, $\left.\mathrm{CH}_{3}\right) . \mathrm{MS}, \mathrm{m} / \mathrm{z}(\%)$ of $7 \mathrm{c}: 425.3\left(14, \mathrm{M}^{+}\right), 271.3(5), 257.3$ (50), 242.2 (38), $214.2(27), 173.2$ (100), $159.2(30), 133.2$ (18). 


\section{2-(Benzoxazol-2-ylamino)-6-hydroxy-3H-4-oxopyrimidine (8)}

A mixture of $1(0.7 \mathrm{~g}, 4 \mathrm{mmol})$ and diethyl melonate $(0.65 \mathrm{~g}, 4 \mathrm{mmol})$ in bromobenzene (15 ml) was heated under reflux for $5 \mathrm{~h}$. The reaction mixture was allowed to attain room temperature where a reddish solid product separated out. It was then filtered, washed with ethanol, dried and recrystallized. The physicochemical and analytical data are recorded in table $2 . \quad I R\left(\mathrm{~cm}^{-1}\right): 3710-$ $2490(\mathrm{NH}, \mathrm{CH}, \mathrm{OH}) ; 1666(\mathrm{C}=\mathrm{O}$ amide I);1644, 1609, 1595, 1547, $1470(\mathrm{C}=\mathrm{N}$, amide II, Ar); $1262(\mathrm{C}-\mathrm{O}-\mathrm{C}) . \quad{ }^{\mathrm{I}} \mathrm{H}-\mathrm{NMR}: \delta 11.6(\mathrm{bs}, 1 \mathrm{H}, \mathrm{N} H) ; 8.0\left(\mathrm{~s}, 1 \mathrm{H}\right.$, pyrimidine $\left.\mathrm{C}_{5}-H\right) ; 7.35(\mathrm{dd}, J=4 \mathrm{~Hz}$, 2H, Ar-H); 7.16 (dd, $J=4 \mathrm{~Hz}, 2 \mathrm{H}, \mathrm{Ar}-H) ; 3.57$ (bs, $1 \mathrm{H}, \mathrm{OH})$. MS, m/z (\%): $244.2\left(4, \mathrm{M}^{+}\right), 226.1$ (4), 202.1 (39), 179.1 (4), 159.1 (44), 134.1 (100), 105.1(23).

\section{2-(Benzoxazol-2-ylamino)-4,6-dichloropyrimidine (9)}

2-(Benzoxazole-2-yalamino)-6-hydroxy-3H-4-oxopyrimidine $8(0.5 \mathrm{~g}, 2 \mathrm{mmol})$ was refluxed with phosphorus oxychloride $(5 \mathrm{ml})$ for $5 \mathrm{~h}$. Excess phosphorus oxychloride was removed under reduced pressure and the remaining dark residue was treated with cold water then neutralized with solid sodium carbonate. The precipitate thus formed was filtered, washed thoroughly with water, dried and recrystallized. The physicochemical and analytical data are recorded in table $2 . \quad I R\left(\mathrm{~cm}^{-}\right.$ l): $3710-2860(\mathrm{NH}, \mathrm{CH}) ; 1642,1562,1535,1498,1458$ (C=N, Ar); 1262 (C-O-C); 744 (C-C1). MS, m/z (\%): $280.0\left(41, M^{+}\right), 245.2(38), 160.2(42), 135.2(100), 109.1(55)$.

\section{2-(Benzoxazol-2-ylamino)-6-hydroxy-5-substituted-3H-4-oxopyrimidines (10a-c)}

2-Guanidinobenzoxazole $1(0.5 \mathrm{~g}, 3 \mathrm{mmol})$ and the appropriate substituted diethyl melonate (6 $\mathrm{mmol}$ ) were heated at $200^{\circ} \mathrm{C}$ in an oil bath for 1-2 h. After being cooled to room temperature, the product was treated with cold ethanol, filtered, washed, dried and recrystallized. The physicochemical and analytical data are recorded in table 2. IR (cm-1): 3470-2495 (NH, CH, 
Synthesis and in vitro Anti-HIV Screening of Certain 2-(Benzoxazol-2-ylamino)-3H-4- ... 71

$\mathrm{OH}) ; 1699-1670(\mathrm{C}=\mathrm{O}$ amidel$) ; 1643,1617,1595,1572,1445(\mathrm{C}=\mathrm{N}, \mathrm{C}=\mathrm{C}$, amide II, Ar); 1262 (CO-C). ${ }^{~} \mathrm{H}-\mathrm{NMR}$ of $10 \mathrm{c}: \delta 12.3$ (bs, $\left.1 \mathrm{H}, \mathrm{NH}\right) ; 7.46(\mathrm{dd}, J=4 \mathrm{~Hz}, 2 \mathrm{H}, \mathrm{Ar}-H) ; 7.38(\mathrm{dd}, J=4 \mathrm{~Hz}, 2 \mathrm{H}$, Ar- $H$ ); $7.24-7.09\left(\mathrm{~m}, 5 \mathrm{H}, \quad\right.$ Ar- $H$ ); $3.76(\mathrm{bs}, 1 \mathrm{H}, \mathrm{OH}) . \mathrm{MS}, \mathrm{m} / \mathrm{z}(\%)$ of $10 \mathrm{c}: 320.2\left(98, \mathrm{M}^{\dagger}\right), 235.1$ (7), $203.2(100), 159.2(32), 134.2(41), 118.2$ (69), $104.2(11)$.

\section{5-Arylazo-2-(benzoxazol-2-ylamino)-6-hydroxy-3H-4-oxopyrimidines (11a-c)}

A cooled freshly prepared solution of the appropriate 4-substituted aniline diazonium chloride (2 mmol) was added dropwise to a cooled stirred mixture of 2-(benzoxazole-2-ylamino)-6-hydroxy3H-4-oxopyrimidine $8(0.5 \mathrm{~g}, 2 \mathrm{mmol})$, sodium acetate trihydrate $(0.55 \mathrm{~g}, 4 \mathrm{mmol})$, sodium hydroxide $(0.4 \mathrm{~g}, 10 \mathrm{mmol})$, water $(5 \mathrm{ml})$ and ethanol $(15 \mathrm{ml})$. Cooling and stirring were maintained for $1 \mathrm{~h}$, then the reaction mixture was acidified with dilute hydrochloric acid to $\mathrm{pH} 4$. The separated deep red colored product was filtered, washed thoroughly with water, dried and recrystallized. The physicochemical and analytical data are recorded in table 2. IR $\left(\mathrm{cm}^{-1}\right)$ : 3710-2955 (NH, CH, OH); 1700-1665 (C=O amide I); 1600, 1526, 1459, $1435(\mathrm{C}=\mathrm{N},-\mathrm{N}=\mathrm{N}-$, amide II, Ar); 1154-1097 (C-OC). ${ }^{1} \mathrm{H}-\mathrm{NMR}$ of $11 \mathrm{~b}: \delta 13.2$ (bs, $1 \mathrm{H}, \mathrm{N} H$ ); $7.84-7.16$ (m, 8H, Ar- $H$ ); 4.17 (bs, $1 \mathrm{H}, \mathrm{OH}$ ). MS, m/z (\%) of 11a: $382.8\left(15, \mathrm{M}^{+}\right), 271.3(4), 251.3(50), 202.2(46), 159.2(28), 134.2(100)$.

\section{B. In vitro anti-HIV screening}

The in vitro drug testing system was performed in the National Cancer Institute's Developmental Therapeutics Program (DTP), AIDS antiviral screening program, according to a reported method ${ }^{26,27}$. The assay involved killing of $\mathrm{T}_{4}$ lymphocytes by HIV. $\mathrm{T}_{4}$ lymphocytes (CEM cell line) were exposed to HIV at a virus-to-cell ratio approximately 0.05 and treated with the test compounds, dissolved in dimethyl sulfoxide, at doses ranging from $10^{-8}$ to $10^{-4} \mathrm{M}$. A complete cycle of virus replication is necessary to obtain the required cell killing (incubation at $37^{\circ} \mathrm{C}$ in a $5 \%$ 
carbon dioxide atmosphere for 6 days). Uninfected cells treated with the test compound were taken as toxicity control, whereas infected and uninfected cells without the test compound served as basic controls. After the incubation period has been completed, tetrazolium salt XTT was added to all wells, and cultures were further incubated to allow formazan color development by viable cells. Formazan production was measured spectrophotometrically and possible protective activity was confirmed by microscopic detection of viable cells. The effect of each compound on the cell growth of HIV-infected and uninfected cells was compared with zidovudine (AZT); the positive control was carried out at the same time under the same conditions.

\section{Acknowledgments}

The authors are very grateful to staff members of the National Cancer Institute's Developmental Therapeutics Program (DTP), for carrying out the AIDS antiviral screening. Extendable thanks are conveyed to Prof. Dr. E. A. M. Badawey for his generous support with valuable chemicals.

\section{References}

1. Barre-Sinoussi F., Cherman J. C., Rey F., Nugeyre M. T., Chamaret S., Gruest J., Dauguet C., Axler-Blin C., Vezinet-Brun F., Rouzioux C., Rosenbaum W., Montagnier M. (1983), Science 220: 868 .

2. Esparsa J. (2001), Bull. WHO 79: 1133.

3. Nagelkerke N. J. D., Iha P., de Vals S. J., Korenromp E. L., Moses S., Blanchard J. F., Plummer F. A. (2002), Bull. WHO 80: 89.

4. Hoegberg M., Sahlberg C., Engelhardt P., Noreen R., Kangasmetsae J., Johannson N. G., Oeberg B., Vrang L., Zhang H., Sahlberg B-L., Unge T., Loevgren S., Fridborg K., 
Baeckbro K. (1999), J. Med. Chem. 42: 4150.

5. Salyers A. A., Whitt D. D. (2001), Microbiology Diversity, Disease and the Environment, 1st Ed., Fitzgerald Science Press, Bethesda, Maryland, p. 382.

6. Katzung B. G. (2001), Basic and Clinical Pharmacology, 8th Ed., Lange Medical Books, McGraw-Hill, USA, p. 831.

7. Hoffman J. M., Wai J. S., Thomas C. M., Levin R. B., O’Brien J. A., Goldman M. E. (1992), J. Med. Chem. 35: 3784.

8. De Clercq E. (1999), Il Farmaco 54; 26.

9. Spence R. A., Kati W. M., Anderson K. S., Johnson K. A. (1995), Science 267: 988.

10. Myeck M. J., Harvey R. A., Champe, P. C. (2000), Pharmacology, 2nd Ed., Lippencott Williams \& Wilkins, Philadelphia, p. 461.

11. Hirsch M. S. (1997), Antiviral Ther. 2: 19.

12. Saari W. S., Wai J. S., Fisher T. E., Thomas C. M., Hoffman J. M., Rooney C. S., Smith A. M., Johns A. H., Bamberger D. L., Goldman M. E., O’Brien J. A., Nunberg, J. H., Quintero J. C., Schleif W. A., Emini E. A., Anderson P. S. (1992), J. Med. Chem. 35: 3792.

13. Nofal Z. M., El-Zahar M. I., Abd El-Karim S. S. (2000), Molecules 5: 99.

14. Sener E. A., Bingoel K. K., Oeren I., Arpaci O. T., Yalcin, I., Altanlar N. (2000), Il Farmaco 55: 469 .

15. Burkholder C. R., Dolbier W. R., Medebielle M. (2000), J. Flour. Chem. 102: 369.

16. Ranft D., Seyfarth T., Schaper K-J., Lehwark-Yvetot G., Bruhn C., Buege, A. (1999), Arch. Pharm. Pharm. Med. Chem. 332: 427.

17. Lecubin F., Fourrey J. L., Sun J-S, Benhida R. (1999), Nucleosides Nucleotides 18: 1609.

18. Van derpoorten K., Ucar H., Andrei G., Snoeck R., Balzarini J., De Clercq E., Poupaert J. H. (1999), Antiviral Chem. Chemother. 10: 87. 
19. Kappe C. O. (2000), Eur. J. Med. Chem. 35: 1043.

20. Pandeya S. N., Sriram D., Nath G., De Clercq E. (1999), Il Farmaco 54: 624.

21. Al-Soud Y. A., Al-Masoudi N. A. (1999), Arch. Pharm. Pharm. Med. Chem. 332: 143.

22. Badawey E. A. M., Kappe, T. (1997), Arch. Pharm. Pharm. Med. Chem. 330: 59.

23. Singh S. P., Prakash I., Tomer R. K., Prakash O. M., Sawhney S. N. (1983), Indian J. Chem. 22B: 37 .

24. Dersch F., De Angelus M. R. (1962), U.S. 3,023,103, 1962; C. A. 57: 325h.

25. Garg H. G., Singh P. P. (1970), J. Chem. Soc. 656.

26. Vince R., Hua M., Brownell J., Daluge S., Lee, F., Shannon W. M., Lavelle G. C., Qualls J., Weislow O. S., Kiser R., Canonico P. G., Schultz R. H., Narayanan V. L., Mayo G., Shoemaker R. H., Boyd M. R. (1988), Biochem. Biophys. Res. Commun. 156: 1046.

27. Weislow O. S., Kiser R., Fine D. L., Bader J., Shoemaker R. H., Boyd M. R. (1989), J. Natl. Cancer Inst. 81: 577. 